\title{
Honeybee venom: influence of collection on quality and cytotoxicity
}

\author{
Allyson Fortunato Abrantes ${ }^{1}$ Thayse Cavalcante da Rocha ${ }^{2}$ \\ Amanda Beatriz Sales de Lima $^{3}$ Mônica Tejo Cavalcanti ${ }^{3}$
}

'Programa de Pós-graduação em Sistemas Agroindustriais, Universidade Federal de Campina Grande (UFCG), 58840-000, Pombal, PB, Brasil. E-mail: abrantes2826@hotmail.com. Corresponding author.

${ }^{2}$ Programa de Pós-graduação em Ciência e Tecnologia de Alimentos, Universidade Federal da Paraíba (UFPB), João Pessoa, PB, Brasil.

${ }^{3}$ Unidade Acadêmica de Tecnologia Alimentos, Universidade Federal de Campina Grande (UFCG), Pombal, PB, Brasil.

\begin{abstract}
Apitoxin is the venom produced by bees. It is a complex chemical compound, rich in protein substances and with pharmacological effects. This study was carried out with the objective of comparing the quality of apitoxin extracted in an apiary in different parts of the collector in relation to moisture content, protein analysis and cytotoxicity assay with Artemia salina L. Type 1 apitoxin was collected from glass slabs at the entrance to the hive, while type 2 apitoxin was collected from the waste accumulated in the collection rods and treated by rinsing in distilled water. Both apitoxins presented significant differences $(P>0.05)$ in relation to protein profile, with type 1 showing a higher content $(77.8 \%)$ than type $2(51.9 \%)$, and presented polypeptide bands with more than $50 \%$ of their nitrogenous components having molecular weight below 10KDa. Regarding cytotoxicity assays, type 1 apitoxin had LD50 of $71.5 \mu \mathrm{g} \mathrm{mL} L^{-1}$, while type 2 had LD50 of $191.6 \mu \mathrm{g} L^{-1}$. Thus, the region where apitoxin accumulates in the collector does influence the product quality if moisture and protein contents are in accordance with the standards recommended in specific legislation, and so it can be commercialized by the beekeeper.

Key words: bees, beekeeping, bee venom, Artemia salina L.
\end{abstract}

Veneno de abelha: influência da coleta em qualidade e citotoxicidade

RESUMO: A apitoxina é o veneno produzido pelas abelhas, um composto químico complexo, rico em substâncias proteicas e com efeito farmacológico. Com objetivo de comparar a qualidade da apitoxina extraída em apiário em relação ao teor de umidade, análise das proteínas e ensaio de citotoxicidade frente Artemia salina L. este trabalho foi realizado. A apitoxina denominada neste estudo como tipo 1 foi coletada de placas de vidro na entrada da colmeia, enquanto que a denominada tipo 2, coletada a partir dos resíduos acumulados nas varetas coletoras e tratada com lavagem em água destilada. As apitoxinas apresentaram diferenças significativas $(P>0,05)$ em relação ao perfil proteico, sendo a tipo 1 com maior teor $(77,8 \%)$ que a tipo $2(51,9 \%)$ e apresentou bandas de polipeptídios reveladas possuindo mais de $50 \%$ de seus componentes nitrogenados com peso molecular abaixo de $10 \mathrm{KDa}$. Quanto aos ensaios de citotoxicidade, a apitoxina tipo 1 apresentou DL50 de $71,5 \mu \mathrm{g}$ mL $L^{-1}$. a tipo 2 DL50 191,6 $\mu \mathrm{g} \mathrm{mL}$. Assim, a região onde se acumula a apitoxina no coletor influencia na qualidade do produto, mas apresenta teores de umidade e proteína de acordo com padrões preconizados em legislação especifica, podendo ser comercializada pelo apicultor.

Palavras-chave: abelhas, apicultura, veneno, Artemia salina L.

\section{INTRODUCTION}

Animal venoms and toxins consist of proteins and peptides with potential medical and biotechnological use. Apitoxins are produced and secreted through a gland (acid gland) located in the posterior region of the Apis mellifera bee's abdomen, containing a complex mixture of substances with biological activity (ORŠOLIĆ, 2012; DANNEELS et al., 2015; SOBRAL et al., 2016) composed of enzymes, peptides, amino acids and other compounds (SCIANI et al., 2010; FERREIRA-JUNIOR et al., 2010). Apitoxin constituents have been used as analgesic, anticoagulant and anti-inflammatory agents for treating chronic diseases such as arthritis, rheumatism, tendinitis, bursitis, fibrosis, multiple sclerosis (SOBRAL et al., 2016), and antineoplastic (ORŠOLIĆ, 2012), and has also been recently studied for its anti-acne (HAN et al., 2016) and antifungal actions (LEE, 2016).

Melittin is the main constituent of apitoxin (SOBRAL et al., 2016). It has a low molecular weight $(2.85 \mathrm{kDa})$ representing about $40-50 \%$ of apitoxin dry weight (GAJSKI et al., 2013; YILMAZ et al., 2016), where it synergistically acts with phospholipase A2 
(molecular weight $11 \mathrm{kDa}$ ) which represents $11 \%$ of apitoxin dry weight (FERREIRA JUNIOR et al., 2010). Furthermore, apamines are also present in a smaller proportion (2-3\%), being a low molecular weight peptide $(2 \mathrm{kDa})$. Concentration of constituents present in apitoxin may vary depending on seasonality, influencing the protein content of the venom (FERREIRA-JUNIOR et al., 2010; SILVEIRA et al., 2015), and also in relation to bees age (DONG et al., 2015).

Bee venom is extracted using a collector composed of plates and a pulse generator, which induces the bees to sting the electric collector plate resting on a glass plate (DANTAS et al., 2013). Volatile phase of the venom evaporates onto the glass plate, from where the apitoxin is then collected by scraping. However, brown-color venom which is also deposited in the collector filaments requires a treatment in order for the product to obtain the characteristic white powder of the apitoxin.

Brazil has legislation for all bee products derived from beekeeping by Normative Instruction No. 3 of the Ministry of Agriculture Livestock and Supply (BRAZIL, 2001). Technical regulation for identity and quality of apitoxin determines requirements of $3 \%$ maximum moisture of the product and protein content ranging from 50 to $85 \%$. It is also indicated that the product packaging must be made with materials suitable for storage conditions and that they provide appropriate protection against contamination; and no additives to the product are authorized.

From the above, this study aimed to analyze the quality of collected apitoxin from the collector filaments after beneficiation and to compare it with the apitoxin collected directly from collector's glass plate, considering moisture content, protein and toxicity through Artemia salina L. bioassay, seeking to establish product quality.

\section{MATERIALS AND METHODS}

Apitoxin used in this study was collected from an apiary located in the municipality of Ceará Mirim, Rio Grande do Norte, Brazil (longitude $36^{\circ} 25^{\prime} 32^{\prime \prime}$ and latitude $\left.5^{\circ} 38^{\prime} 04^{\prime \prime}\right)$, in the months of January and February of 2015. Samples used in this study were obtained from three different lots, lot contained about 10 swarms, and sent to the Laboratory of Technology of Animal Origin of the Agro-Food Science and Technology Center at the Universidade Federal de Campina Grande.

Collection procedure used was the electric collector method, composed of stainless steel electrodes connected to a battery and glass slide positioned at the hive entrance. When the bees land on the collector, they received a shock and react by stinging the electric collector plate, depositing a load of venom on the glass, as well as on the equipment filaments, where it dries and is subsequently scraped and commercialized.

The apitoxin in this study was denominated as type 1 apitoxin. It is the material collected directly from the glass plates scraped with steel blades after natural dehydration and marketed directly in this form. Type 2 apitoxin is removed from the material accumulated in the equipment filaments (collecting ditches), which is scraped with steel sheets after its natural dehydration, washed in distilled water $(1: 3 \mathrm{w} / \mathrm{v})$, filtered on qualitative filter paper $(125 \mathrm{~mm})$ and then dried at a temperature of $30^{\circ} \mathrm{C}\left( \pm 5^{\circ} \mathrm{C}\right)$ in an air circulating oven.

Apitoxin was analyzed for its moisture content using a moisture-determining scale (MARTE brand) at a temperature of $105^{\circ} \mathrm{C}$ until constant weight of the sample (in triplicate). Protein content was determined by the Micro-Kjeldahl method in triplicate, using a factor of 6.25 for transformation of total nitrogen into proteins as recommended by the AOAC (2010).

Moisture content and protein analyzes were submitted to statistical analysis for mean comparison using $t$ student test, considering a level of probability error (p) less than 5\% to determine significance using the Assistat 7.6 free statistical program (SILVA, 2014).

PAGE-SDS-2ßMe system polyacrylamide gel electrophoresis was carried out according to the methodology described by LAEMMLI(1970), adapted for the use of plaque separation gels $(10 \times 10 \times 0.1 \mathrm{~cm})$ (Kasvi brand), where application gel containing 6\% polyacrylamide was prepared in $0.6 \mathrm{Mol} \mathrm{L}^{-1}$ Tris- $\mathrm{HCl}$ buffer, $6.8 \mathrm{pH}$ and 1.0\% SDS (w/v) (sodium dodecyl sulfate). The $15 \%$ polyacrylamide gradient separation gel was prepared in $3.7 \mathrm{Mol} \mathrm{L}-1$ Tris- $\mathrm{HCl}$ buffer, 8.9 $\mathrm{pH}$ containing $1.0 \%$ SDS. Electrophoris was run at a constant voltage of $200 \mathrm{~V}$ with gel stained for 12 hours with Coomassie Blue Brilliant R-250 0.05\% prepared in methanol, acetic acid, water (1:3.5:8, $\mathrm{v} / \mathrm{v} / \mathrm{v}$ ) and gel decolorization using methanol, acetic acid and water (1:3.5:8, v/v/v). Molecular weight markers used were 17, 14.2, 6.5, 3.49 and $1.06 \mathrm{kDa}$ (M 3546, SIGMA - Molecular Weight Marker, Ultra Low Range for SDS-PAGE).

The stained gel was photographed in a scanner and the obtained image was processed by Image J software (IMAGEJ, 2015), where the visible bands were related through densitometric analysis. Artemia salina L. bioassay was performed according to the technique described by MEYER et al. (1982), using a mixture of seawater and distilled 
water as the saline solution $(1: 1, \mathrm{v} / \mathrm{v})$, where the microcrustacean eggs $(0.2 \mathrm{~g})$ were incubated for 48 hours in a cage built with screens to prevent insect entry, aeration with a specific pump and direct incidence of light (60W lamp). After hatching, 10 nauplii/larvae were transferred to test tubes containing $5.0 \mathrm{~mL}$ of saline water with the apitoxin concentrations varying from 0 to $500 \mu \mathrm{g} \mathrm{mL}^{-1}$. Each concentration tested was performed in triplicate. Dead larvae count was performed after 24 hours and used for calculating LD 50, a lethal dose to $50 \%$ of the larval population, determined from PROBIT analysis (FINNEY, 1962) using BioStat ${ }^{\circledR}$ 2009 software, with $95 \%$ confidence.

\section{RESULTS AND DISCUSSION}

The apitoxin accumulated and removed from the collector equipment's protective material (type 2) has a brown color, and it becomes white after the beneficiation process with visible diminution of impurities.

Regarding the moisture content, type 1 and type 2 apitoxin presented values of $2.5 \%( \pm 0.15)$ and $3.0 \%( \pm 0.15)$, respectively, not being statistically different $(\mathrm{P}>0.05)$ and complying with the legislation enforced in Brazil (BRAZIL, 2001).

Apitoxin processed using the analyzed methods showed different results regarding protein content; however, it was within the recommended legislation with protein contents between 50 and $85 \%$ (BRAZIL, 2001). The beneficiation process through rinsing and filtration methods (type 2 apitoxin) led to a decrease in the sample's protein content through solubilization, differing statistically $(\mathrm{p}>0.05)$ with protein content at $51.9 \%( \pm 0.56)$, while apitoxin collected directly from the collector glass plates (type 1 apitoxin) had a higher protein content at $77.8 \%( \pm 0.93)$.

In analyzing polypeptide bands revealed by electrophoretic analysis (Figure 1) through densitometry analysis, we observed that both apitoxins presented a similar protein profile independent of collection site, with well-pronounced lower molecular weight fractions below $10 \mathrm{kDa}$. The analysis also indicated the presence of melittin $(2.8 \mathrm{kDa})$, equivalent to $53.5 \%$ melittin for type 1 apitoxin, and 50.2\% melittin for type 2 apitoxin. Fraction between 15 and $10 \mathrm{KDa}$ indicated A2 phospholipase content $(11 \mathrm{kDa})$, presenting around $32 \%$ for type 1 and 2 . Low molecular weight peptides such as melittin, considered a quality marker of apitoxin (SOBRAL et al., 2016; GAJSKI et al., 2013;
YILMAZ et al., 2016) is present in similar amounts in both forms of analyzed beneficiations.

Both type 1 and type 2 apitoxin presented reduced Artemia salina L. naupili/larvae viability depending on the concentration tested, with LD50 of $71.5 \mu \mathrm{g} \mathrm{mL}^{-1}$ and $191.6 \mu \mathrm{g} \mathrm{mL}^{-1}$ respectively, with bioactive action being considered for presenting LD50 values lower than $250 \mu \mathrm{g} \mathrm{mL}^{-1}$ (SIQUEIRA et al., 1998; DANTAS et al., 2013). Apitoxin biological activity is related to the bioactive action of its chemical constituents (GAJSKI et al., 2013).

Thus, type 1 apitoxin had greater bioactivity than type 2 apitoxin, possibly due to its higher protein content. Such a fact may be related to protein loss during the beneficiation process in type 2 apitoxin.

From the proposed processing technique, the material previously discarded by beekeepers leads to an increase in apitoxin yield from collection of around $40 \%$, which in practice represents a substantial financial gain for beekeepers.

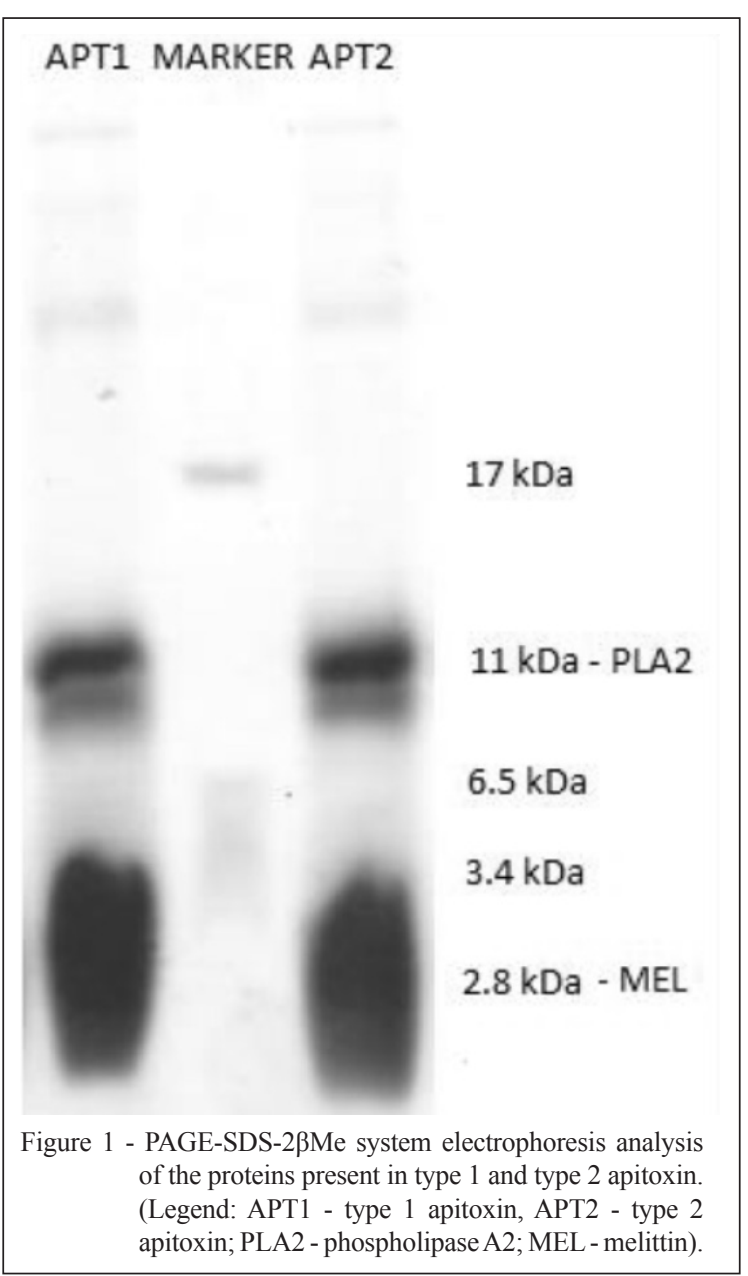

Ciência Rural, v.47, n.10, 2017. 


\section{CONCLUSION}

The apitoxin presented low molecular weight peptides in similar amounts and bioactive action. Thus, the region where apitoxin accumulates in the collector does influence the product quality and biological activity if moisture and protein contents are in accordance with the standards recommended in specific legislation, and so it can be commercialized by the beekeeper. Finally, we suggested beekeepers implementing the collection of apitoxin from collector filaments (on its own or mixed with samples obtained from the glass plates) since they have similar characteristics.

\section{REFERENCES}

ASSOCIATION OF OFFICIAL ANALITYCAL CHEMISTRY. Official Methods of Analysis. Washington D.C.: AOAC International, 2010.

BRAZIL. Instrução Normativa n.3, de 19 de janeiro de 2001. Ministério da Agricultura, Pecuária e Abastecimento aprova os regulamentos técnicos de identidade e qualidade de apitoxina, cera de abelha, geléia real, geléia real liofilizada, pólen apícola, própolis e extrato de própolis. In: MINISTERIO da Agricultura, Pecuária e Abastecimento. Available from: <http://extranet.agricultura.gov.br/sislegis-consulta/ consultarLegislacao.do?operacao=visualizar\&id $=1798>$. Accessed: July 22, 2016 .

DANNEELS, E.L. et al. Honeybee venom proteome profile of queens and winter bees as determined by a mass spectrometric approach. Toxins, v.7, n.11, p.4468-4483, 2015. Available from: <http://www. mdpi.com/2072-6651/7/11/4468>. Accessed: July 22, 2016. doi: 10.3390/toxins 7114468

DANTAS, C.G. et al. Apitoxina: coleta, composição química, propriedades biológicas e atividades terapêuticas. Revista IberoAmericana de Ciências Ambientais, v.4, n.2, p. 127-150, 2013. Available from: $<$ https://www.researchgate.net/publication/276318510 Apitoxina coleta composicao quimica propriedades biologicas e atividades_terapeuticas $>$. Accessed: July 22, 2016. doi: 10.6008/ ESS2179-6858.2013.002.0009.

DONG, J. et al. High-performance liquid chromatography combined with intrinsic fluorescence detection to analyse melittin in individual honeybee (Apis mellifera) venom sac. Journal of Chromatography B., v.1002, p.139-143, 2015. Available from: <http://www. sciencedirect.com/science/article/pii/S1570023215301422>. Accessed: July 22, 2016. doi: 10.1016/j.jchromb.2015.08.014.

FERREIRAJUNIOR, R.S. et al. Africanized honey bee (Apis mellifera) venom profiling: seasonal variation of melittin and phospholipase A2 levels. Toxicon, v.56, n.3, p.355-362, 2010. Available from: $<$ http:// www.sciencedirect.com/science/article/pii/S004101011000142X>. Accessed: July 17, 2016. doi: 10.1016/j.toxicon.2010.03.023.

FINNEY, D.J. Probit Analysis. Cambridge: Cambridge University, 1962. Available from: <http://www.jstor.org/stable/41139025>. Accessed: Jan. 20, 2016.

GAJSKI, G. et al. Melittin: a lytic peptide with anticancer properties. Environmental Toxicology and Pharmacology, v.36, n.2, p.697-705, 2013. Available from: <http://www.sciencedirect. com/science/article/pii/S1382668913001415>. Accessed: Feb. 10, 2017. doi: 10.1016/j.etap.2013.06.009.

HAN, S.M. et al. Evaluation of anti-acne property of purified bee venom serum in humans. Journal of Cosmetic Dermatology, v.15, n.4, p.16, 2016. Available from: <http://onlinelibrary.wiley.com/doi/10.1111/ jocd.12227/epdf $>$. Accessed: July 20, 2016. doi: 10.1111/jocd.12227.

IMAGEJ - Image Processing and Analysis in Java. Online. Available from: <http://imagej.nih.gov/ij/index.html>. Accessed: Dec. 15, 2015

LEE, S. Antifungal activity of bee Venom and Sweet Bee Venom against Clinically Isolated Candida albicans. Journal of Pharmacopuncture, v.19, n.1, p.45-50, 2016. Available from: <http://www.journal.ac/sub/ view/161>. Accessed: July 20, 2016. doi: 10.3831/KPI.2016.19.006.

LAEMMLI, U.K. Cleavage of structural proteins during the assembly of the head of the bacteriophage. Nature, v.227, p.689-95, 1970. Available from: <http://dx.doi.org/10.1038/227680a0>. Accessed: Dec. 10, 2015. doi:10.1038/227680a0.

MEYER, B.N. et al. Brine shrimp, a conveniente general bioassy for active-plant constituints. Planta Medicinal, v.45, p.31-34, 1982. Available from: <http://dx.doi.org/10.1055/s-2007-971236>. Accessed: Jan. 27, 2016. doi: 10.1055/s-2007-971236.

ORŠOLIĆ, N. Bee venom in cancer therapy. Cancer Metastasis Reviews, v.3, p.173-194, 2012. Available from: <http://www.ncbinlm. nih.gov/pubmed/22109081>. Accessed: July 15, 2016. doi: 10.1007/ s10555-011-9339-3.

SCIANI, J.M. et al. Identification of a novel melittini so form from Africanized Apis mellifera venom. Peptides, v.31, n.8, p.1473-1479, 2010. Available from: $<$ http://www.sciencedirect.com/science/article/ pii/S0196978110002056>. Accessed: July 21, 2016. doi: 10.1016/j. peptides.2010.05.001.

SILVA, F.A.S. ASSISTAT: versão 7.7 beta. DEAG-CTRN-UFCG - Atualizado em 01 de abril de 2014. Available from: <http://www. assistat.com/>. Accessed: Jan. 20, 2016.

SIQUEIRA, J.M. et al. Activity - guided isolation of constituents of Unonopsis Lindmanii-Annonaceae, based on the brine shrimp lethality bioassay Artemia salina Leach. Química Nova, v.21, n.5, p.557-559, 1998. Available from: <http://www.scielo.br/pdf/qn/v21n5/2923.pdf >. Accessed: July 21, 2016.

SILVEIRA, D.C. et al. Variações diurna e sazonal da defensividade das abelhas africanizadas (Apis mellifera L.). Revista Brasileira de Saúde e Produção Animal, v.16, n.4, p.925-934, 2015. Available from: <http:// www.scielo.br/pdf/rbspa/v16n4/1519-9940-rbspa-16-4-0925.pdf > . Accessed: July 15, 2016. doi: 10.1590/S1519-99402015000400016.

SOBRAL, F.etal. Chemical characterization, antioxidant, anti-inflammatory and cytotoxic properties of bee venom collected in Northeast Portugal. Food and Chemical Toxicology, v.94, p.172-177, 2016. Available from: http://www.sciencedirect.com/science/article/pii/S0278691516301880. Accessed: July 20, 2016. doi:10.1016/j.fct.2016.06.008.

YILMAZ, U.T. et al. Sensitive voltammetric determination of melittin in honeybee venom powder from Apis mellifera. Microchemical Journal, v.124, p.364-367, 2016. Available from: <http://www.sciencedirect. com/science/article/pii/S0026265X15002222>. Accessed: July 20, 2016. doi: 10.1016/j.microc. 